A. Dudush ${ }^{1}$, I. Sachuk ${ }^{1}$, Salman Owaid ${ }^{2}$, A. Bidun ${ }^{1}$

${ }^{1}$ Ivan Kozhedub Kharkiv National Air Force University, Kharkiv

${ }^{2}$ Al Maaref University Collage, Al Anbar, Iraq

\title{
SCIENCE \& TECHNOLOGY TRENDS IN COGNITIVE RADAR CONCEPT
}

Currently, human operators provide cognition in a radar system. However, advances in the "digitization" of radar front-ends, including digital arbitrary waveform generators $(A W G)$ and advanced high performance embedded computing (HPEC) make it possible to vary all key radar parameters (power, pulse length, number of pulses, pulse repetition frequency (PRF), modulation, frequency, polarization) on a pulse-by-pulse basis within ns or $\mu$ and over a wide operating range. This timescale is much faster than the decision-making ability of a human operator. The cognitive-inspired techniques in radar, that are intensively developing last years, mimic elements of human cognition and the use of external knowledge to use the available system resources in an optimal way for the current goal and environment. Radar systems based on the perception-action cycle of cognition that senses the environment, learns relevant information from it about the target and the background and then adapts the radar to optimally satisfy the needs of the mission according to a desired goal are called cognitive radars. In the article, recent ideas and applications of cognitive radars were analyzed.

Keywords: cognitive radar, space-time adaptive processing (STAP), Bayesian filtering, knowledge-aided radar signal and data processing.

\section{Introduction}

Formulation of the problem. The research and analysis made by the NATO Science \& Technology (S\&T) Organization and underlying in the report "Science \& Technology Trends 2020-2040. Exploring the S\&T Edge" [1] provides an assessment of emerging or disruptive S\&T and their potential impact on NATO military operations, defense capabilities, and political decision space. According to the report, one of the disruptive technologies is Artificial Intelligence.

Artificial Intelligence (AI) refers to the ability of machines to perform tasks that normally require human intelligence - for example, recognizing patterns, learning from experience, drawing conclusions, making predictions, or taking action - whether digitally or as the smart software behind autonomous physical systems.

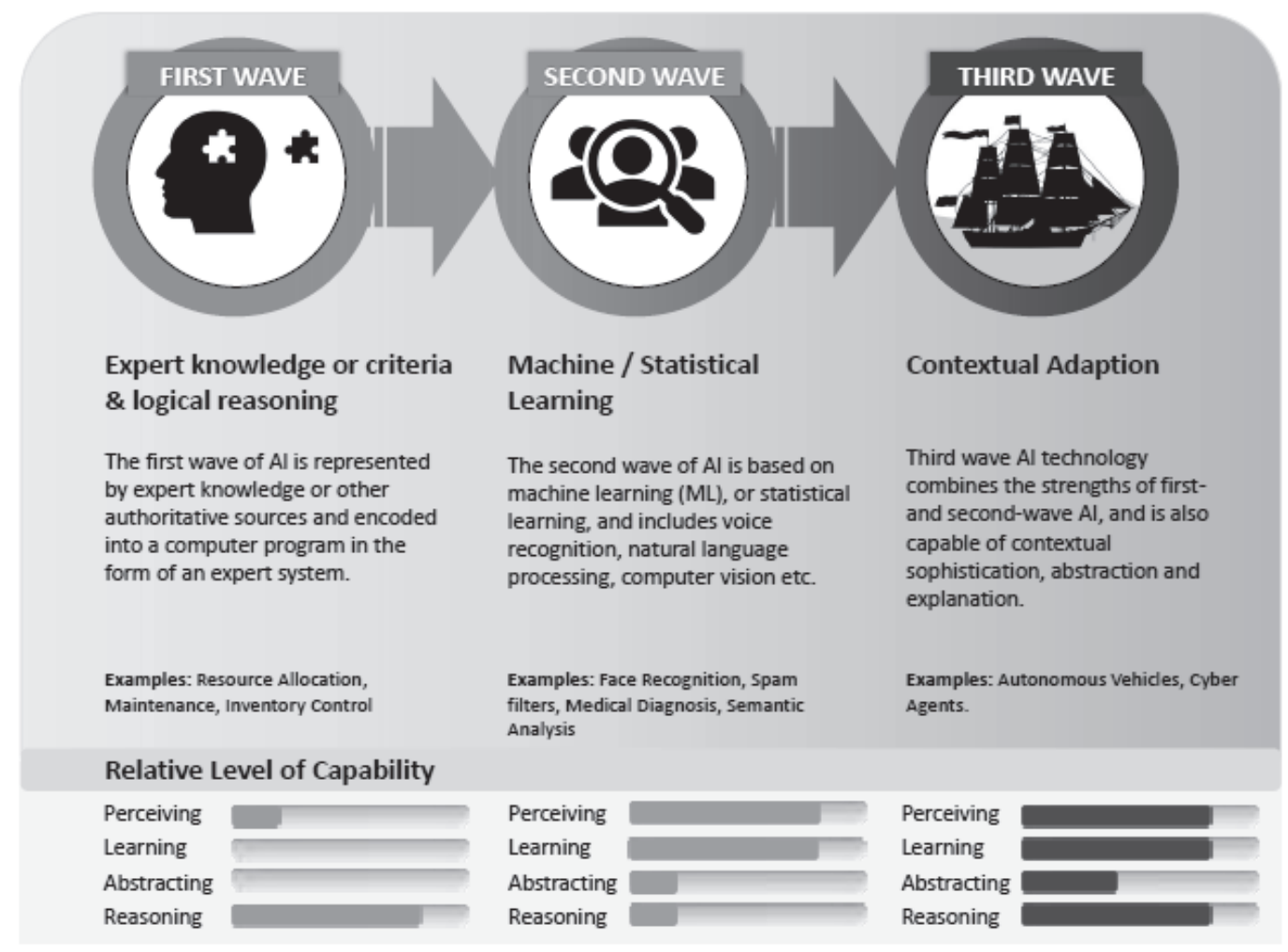

Fig. 1. Three cycles of AI

Source: [1, p. 51]. 
Since its beginnings in the mid-1950s, AI has moved through three development cycles (Fig. 1). The initial period focused on rules-based approaches (decision trees, Boolean and fuzzy logic), e.g. expert systems [2]. The second cycle focused on the development and application of statistical methods (i.e. supervised, unsupervised and reinforcement learning). Such machine learning methods have been highly successful and underlie everything from e-mail spam filtering to internet web searches. The third cycle of development focuses on the use of bio-inspired learning methods (neural networks, deep learning), with considerable success in the areas of sensing and perception [3].

AI faces a number of critical challenges or areas of research. Advances are necessary in the following areas: Advanced Algorithms, Human-Machine Symbiosis, AI Application. There is a need for processes to transform both structured data (e.g. machine learning techniques with varying levels of complexity, from regression to neural networks) and unstructured data (e.g. using deep learning and natural language processing) into insights and foresight for decision-makers. These tools may then be applied to critical defense and security challenges such as sensors that can pre-process information and provide adaptive use of frequencies, bandwidth and signals - cognitive radars.

Analysis of recent research and publications. Cognitive radar (CR) - is a radar system that in some sense displays intelligence, adapting its operation and its processing in response to a changing environment and target scene. In comparison to adaptive radar, CR learns to adapt operating parameters as well as processing parameters and may do so over extended time periods [4]. A framework for classification of the $\mathrm{CR}$ and differen- tiation between different levels of adaptivity can be found in [5].

The basic features of a CR are [6]:

1) intelligent signal processing, which builds on learning through interactions of the radar with the surrounding environment;

2) feedback from the receiver to the transmitter, which is a facilitator of intelligence;

3) preservation of the information content of radar returns, which is realized by the Bayesian approach to target detection through tracking.

From signal processing and control theory, we know that it is not necessary for the radar to keep the entire record of past data. Rather, by adopting a statespace model of the environment and recursively updating the state vector representing an estimate of certain parameters pertaining to the environment, the need for storing the entire history of radar data on the environment is eliminated.

The requirement to update estimation of the environmental state is necessitated by the fact that the radar environment is nonstationary. A primary cause of nonstationarity is statistical variations in the weather and the presence of unknown targets at unknown locations. Recursive updating of a state is synonymous with adaptivity, which is the natural method for dealing with nonstationarity. In current designs of radar systems, however, adaptivity is usually confined to the receiver. For the radar to be cognitive, adaptivity has to be extended to the transmitter too. Moreover, the radar has to learn from experience on how to deal with different targets.

Fig. 2 depicts the picture of a cognitive cycle performed by a CR system [6] that illustrates main differences of a $\mathrm{CR}$ from an adaptive radar:

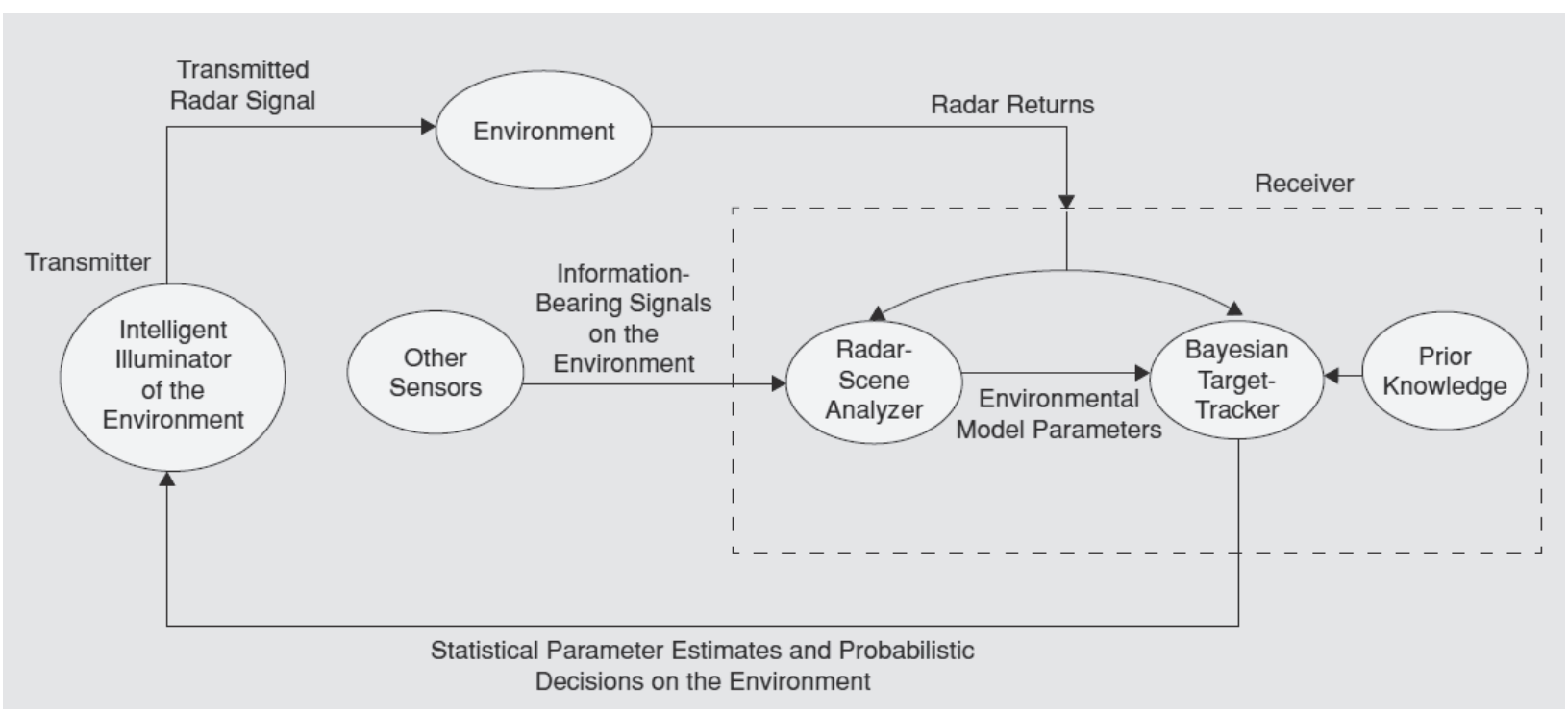

Fig. 2. Block diagram of CR viewed as a dynamic closed-loop feedback system Source: [6, p. 31].

1) the radar continuously learns about the environment through experience gained from interactions with the environment and, in a corresponding way, con- tinually updates the receiver with relevant information on the environment;

2) the transmitter adjusts its illumination of the en- 
vironment in an intelligent manner, taking into account such practical matters as the size of the target and its range, and consequently, making adjustments to the transmitted signal in an effective and robust manner;

3 ) the whole radar system constitutes a dynamic closed feedback loop encompassing the transmitter, environment, and receiver.

Cognition is a two-way process, one being inside out and the other being outside in. The inside-out part of cognition is represented by prior knowledge on the environment, and which is an integral part of the receiver, as shown in Fig. 2. Prior knowledge may be viewed as long-term memory of the receiver.

The outside-in part of cognition may be viewed as short-term memory, which is developed by the receiver on the fly. It is initiated by the radar-scene analyzer in response to information-bearing signals gathered on the outside environment by the radar itself as well as other sensors working cooperatively with the radar.

Conventional adaptive radars rely on sample statistics derived from the received data stream and, consequently, can suffer a loss in performance in highly nonstationary interference environments. For an adaptive radar to be cognitive, it has to satisfy four processes [7]:

1) perception-action cycle for maximizing information gain about the radar environment computed from the observable data;

2) memory for predicting the consequences of actions involved in illuminating the environment and parameter selection for environmental modeling;

3) attention for prioritizing the allocation of available resources in accordance with their importance;

4) intelligence for decision-making, whereby intelligent choices are made in the face of environmental uncertainties.

CRs aim to provide much more sophisticated methods of adaptation using high fidelity contextual (such as environmental) knowledge sources, as well as organic sensor data (Fig. 3) [8]. In contrast to the conventional radar architecture, the $\mathrm{CR}$ has a number of additional subsystems and additional adaptivity:

- Adaptive Transmit Chain;

- Environmental Dynamic Database (EDDB);

- Knowledge-Aided (KA) Coprocessor.

The inclusion of a knowledge-aided (KA) coprocessor and environmental dynamic database (EDDB) allow for the inclusion of new information sources to aid in overall adaptivity. The two main new elements are adaptivity on transmit and the introduction of KA processing. The role of the KA coprocessor and the EDDB is fundamentally to provide an accurate estimate of the dynamic radar channel. The new adaptive transmit chain allows for the channel adaptivity of all transmit degrees-of-freedom (DoF), including waveform, spatial (such as az-el transmit adaptivity), polarimetric, etc.

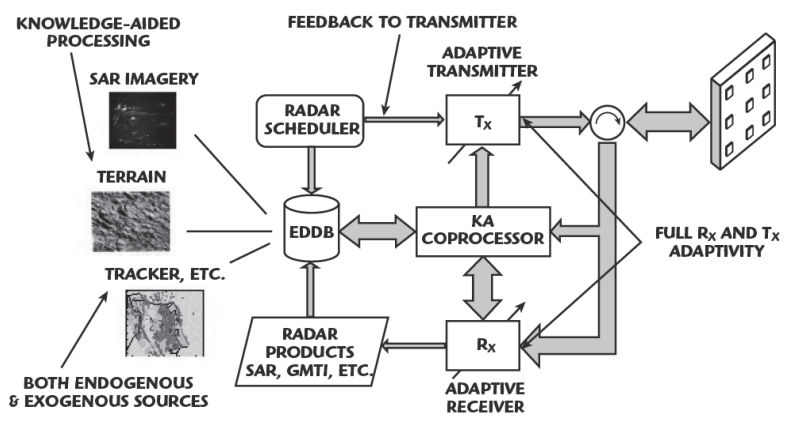

Fig. 3. Example of a knowledge-aided, fully adaptive radar architecture Source: [8, p. 26. ]

The purpose of the article is to analyze recent ideas and applications of cognitive radars.

\section{Statement of basic materials}

Basics of CR. For the CR the optimum transmit and receive functions that maximize output signal-tointerference plus noise ratio (SINR) in the additive colored noise case is [9]:

optimal transmit

$$
\overline{\left(\mathbf{H}^{T} \mathbf{H}\right)} \cdot \mathbf{s}=\lambda \mathbf{s}
$$

optimal receive

$$
\mathbf{w}=\mathbf{R}^{-1} \mathbf{y}
$$

where $\mathbf{H}$ - is the composite statistical channel transfer function (e.g., target and whitening filter);

s - is the optimum transmit signal and is the eigenfunction of (1) with maximum associated eigenvalue;

$\mathbf{y}-$ is the received target of interest echo;

$\mathbf{R}$ - is the covariance matrix (CM) associated with the colored noise;

$\mathbf{w}$ - is the optimal receiver weight vector (colored noise matched filter [10]).

A new approach to form a full-rank estimate of the clutter covariance channel based on the return from a single range bin has been proposed in [11]. This approach based on three independent estimates of the clutter channel associated with a CR.

First, an estimate $\widehat{\mathbf{R}}_{S}$ of the actual interference CM $\mathbf{R}$ is generally obtained from a maximum likelihood (ML) optimization that leads to sample based covariance of the form

$$
\widehat{\mathbf{R}}_{S}=\frac{1}{K} \sum_{k=1}^{K} \mathbf{x}_{k} \mathbf{x}_{k}^{\prime},
$$

where $\mathbf{x}_{k}=\mathbf{H}_{k} \mathbf{s}+\mathbf{n}_{k}$ - the space-time receive array snapshot vector for the $k^{\text {th }}$ range bin with receiver noise $\mathbf{n}$;

$K$ - the total number of samples used;

' - symbol of Hermitian conjugate.

The sample estimate (3) only yields a rank one measurement of the channel transfer function for a 
given range bin. This is why averaging over multiple range bins is required to obtain a full rank ultimately useful estimate of the covariance.

Knowledge of (3) allows to predict what the corresponding channel kernel $\mathbf{H}_{k} \mathbf{H}_{k}^{\prime}$ will be when illuminated with the actual transmit signal versus white noise or an impulse probe. So second is the resulting probe estimate of the form

$$
\widehat{\mathbf{R}}_{M}=\left(\mathbf{H}_{k} \circ \mathbf{S}_{k}\right)\left(\mathbf{H}_{k} \circ \mathbf{S}_{k}\right)^{\prime}=\left(\mathbf{H}_{k} \mathbf{H}_{k}^{\prime}\right) \circ\left(\mathbf{S}_{k} \mathbf{S}_{k}^{\prime}\right),
$$

where $\circ$ - the Hadamard product;

$\mathbf{S}_{k}$ - a matrix that accounts for the transmit steering vector.

A fully CR estimate of $\mathbf{R}$ would have a form

$$
\widehat{\mathbf{R}}_{C R}=c_{1} \widehat{\mathbf{R}}_{S}+c_{2} \widehat{\mathbf{R}}_{M}+c_{3} \widehat{\mathbf{R}}_{K A},
$$

where $\widehat{\mathbf{R}}_{K A}$ - KA sample estimate of $\mathbf{R}$ based on direct methods of prior knowledge incorporation into the adaptive filtering process;

$c_{1}, c_{2}, c_{3} \geq 0$ - weighting factors that reflect the relative confidence in the various estimates.

Several major areas of research and development can be singled out in connection with the CR $[7 ; 12-$ 17]:

1) Bayesian filtering for state estimation of the environment;

2) adaptive waveform design for spectral compatibility and matched illumination;

3) optimization of radar antenna patterns;

4) knowledge-aided radar signal and data processing (detection, classification, tracking);

5) multifunction radar resource management and cost function design;

6) development of assessment and evaluation tools for CR;

7) experimental testing methodologies for CR.

Bayesian filtering for state estimation of the environment. Space-time adaptive processing (STAP) in the context of practical real-world considerations is particularly vulnerable to complex clutter environments due to its need to estimate a generally high dimensional space-time CM $\mathbf{R}$. In practice there is need to use a sample estimate $\widehat{\mathbf{R}}$ of a CM based on $L$ training data samples. If the data samples were drawn from a Gaussian independent and identically distributed (i.i.d.) stochastic process the expected SINR loss ratio (adaptive/ideal), due to finite sample estimation is [18]:

$$
\rho=\frac{L-n+2}{L+1}, L \geq n,
$$

where $n-$ is the number of effective adaptive DOFs.

A useful rule-of-thumb derived from (6) is that, to achieve a loss no greater than $3 \mathrm{~dB}$, at least on order of $2 n$ i.i.d. training samples are required. KA methods can overcome these issues by utilizing other information sources besides the incoming radar data stream [8].
Generally, the incorporation of other knowledge sources into the adaptive filtering process is either direct or indirect. An indirect method consists of a judicious selection of both the available training data and filter structure.

Direct methods of prior knowledge incorporation are generally more complex and difficult to implement, but can yield significantly improved performance in demanding environments. One example, grounded in the incorporation of "prior" information as formulated by Thomas Bayes [19], is to combine an estimate of the underlying clutter CM $\mathbf{R}$ obtained from prior knowledge sources $\widehat{\mathbf{R}}_{0}$, with an estimate $\widehat{\mathbf{R}}_{1}$ obtained using the incoming data stream. For example, according to colored loading or blending approach, this KA sample estimate $\widehat{\mathbf{R}}_{K A}$ has the form [20]:

$$
\widehat{\mathbf{R}}_{K A}=\alpha \widehat{\mathbf{R}}_{0}+\beta \widehat{\mathbf{R}}_{1},
$$

where typically $\alpha, \beta$ satisfy $0 \leq \alpha \leq 1$ and $\beta=1-\alpha$. The above was shown to be the optimum Bayesian estimate of the true underlying covariance $\mathbf{R}$ when $\widehat{\mathbf{R}}_{0}$ and $\widehat{\mathbf{R}}_{1}$ are statistically independent estimates (the weighting coefficients are proportional to the effective amount of training data used to form each constituent covariance estimate, respectively).

Since in practice the quality of the a priori estimate is vulnerable to a number of error sources, a straightforward remedy is to choose $\alpha$ adaptively to maximally whiten the observed interference data. For example [20]:

$$
\min _{\{\alpha\}} \mathbf{Z}_{L}(\alpha)
$$

where

$$
\mathbf{Z}_{L}(\alpha)=\left\|\sum_{k} \mathbf{y}_{k} \mathbf{y}_{k}^{\prime}-I\right\|
$$

and

$$
\mathbf{y}_{k}=\left(\alpha \widehat{\mathbf{R}}_{0}+\beta \widehat{\mathbf{R}}_{1}\right)^{-\frac{1}{2}} \mathbf{x}_{k} .
$$

$$
\left(\alpha \widehat{\mathbf{R}}_{0}+\beta \widehat{\mathbf{R}}_{1}\right)^{-\frac{1}{2}}-\text { is the whitening matrix corre- }
$$

sponding to a particular $\alpha$ and the summation in (8) is performed over a suitable subset of the radar observations for which $\widehat{\mathbf{R}}_{0}$ is believed valid. If an a priori covariance estimate is available for each range bin, then the vector residue (9) can be replaced with

$$
\mathbf{y}_{k}=\left(\alpha \widehat{\mathbf{R}}_{0}(k)+\beta \widehat{\mathbf{R}}_{1}\right)^{-\frac{1}{2}} \mathbf{x}_{k},
$$

where $\widehat{\mathbf{R}}_{0}(k)$ is the a priori estimate for the $k^{\text {th }}$ range bin.

The above adaptive $\alpha$ approach is but a special case of an entire class of direct filtering methods incor- 
porating prior information, i.e., data prewhitening (or simply data detrending).

Bayesian estimation had been compared to existing regularization techniques aimed at "correcting" the ML estimate of a CM by Ya.D. Shirman and V.M. Orlenko [21-22]. The authors proposed to correct the inverse CM estimate $\widehat{\Lambda}_{i}^{-1}$ by subjecting the magnitude of eigenvalues $\Lambda_{\text {samp.i }}$ of the sample matrix to a smooth limitation depending on their relation to the eigenvalues $\Lambda_{0}$ pertaining to internal noise and the sample volume . Fig. 4 shows the resulting relations between the eigenvalues of sample matrix and the inverse $\mathrm{CM}$ estimate given various methods used for obtaining the "corrected" estimates of the latter matrix, the relations being shown in logarithmic scale for the following cases:

1) $\widehat{\Lambda}_{i}^{-1}=\left(\frac{1}{v} \Lambda_{\text {samp.i }}\right)^{-1}$ ML estimate of the inverse CM (3);

2) $\widehat{\Lambda}_{i}^{-1}=\left(\frac{1}{v} \Lambda_{\text {samp. } i}+\beta\right)^{-1} \quad$ regularization technique by Yu.I. Abramovich [23] (given that $\beta=\Lambda_{0}=1$ );

3) $\widehat{\Lambda}_{i}^{-1}= \begin{cases}\left(\frac{1}{v} \Lambda_{\text {samp. } i}\right)^{-1}, & \text { when } \Lambda_{\text {samp. } i}>0 \\ 1 / \sigma_{u}^{2}, & \text { when } \Lambda_{\text {samp. } i}=0\end{cases}$ fast

ML (FML) estimate by Steiner and Gerlach [24];

4) $\widehat{\Lambda}_{i}^{-1}=f\left(\Lambda_{\text {samp.i }}\right)$ optimal Bayesian estimate of inverse CM.

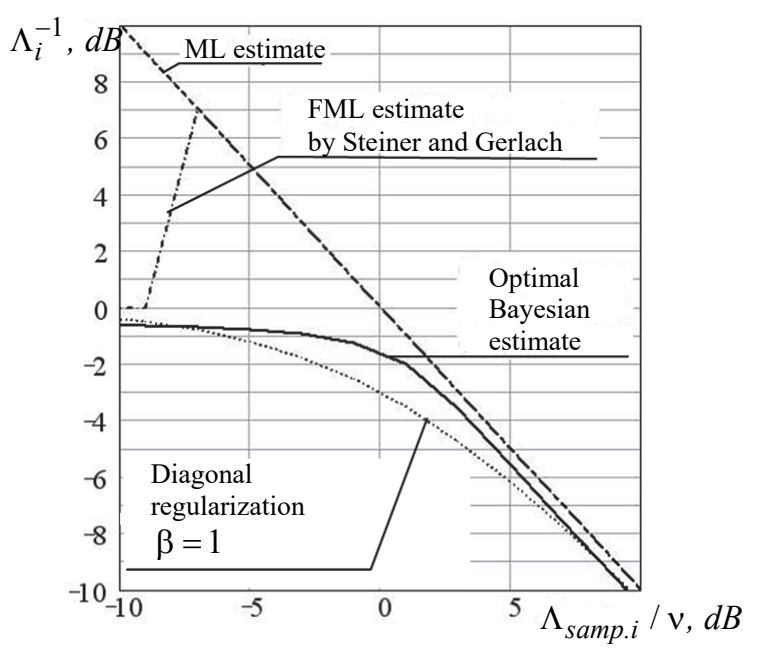

Fig. 4. Resulting relations between the eigenvalues of sample $\mathrm{CM}$ and the inverse $\mathrm{CM}$ estimates Source: [21, p. 438].

Having analyzed the curves shown in Fig. 4 the authors had concluded that Bayesian correction takes an intermediate position right between the diagonal regularization technique by Abramovich and the FML by
Steinberg and Gerlach thus combining advantages of both techniques. However, Bayesian estimates of inverse CM have not been studied any further.

Adaptive waveform design for spectral compatibility and matched illumination. To cope with the issue of spectrum crowding and steadily increasing radar requirements, one solution is intelligent spectrum utilization coupled with agile waveform diversity. The solution leads to the definition of CR systems that are able to find the free portions of the spectrum, where it is possible to transmit and properly react in order to coexist with other RF systems (i.e. communication systems or jammers) operating in the same environment.

In [25] the general problem of a ultra-wideband (UWB) radar that shares the same channel with a communication system and the perception-action cycle of a $\mathrm{CR}$ with the spectrum sensing, the channel characterization and the spectrum sharing functions were described. For predicting the occupancy and estimating the parameters of the channels, hidden Markov models and iterative Baum-Welch method were applied, respectively.

To further increase the spectrum awareness of a $\mathrm{CR}$, the use of a radio environmental map (REM) has been proposed [26]. The REM approach consisted of storing and processing a variety of data to extract all of the available information on transmitter locations, propagation conditions, and spectrum usage in space and time.

With the matched illumination techniques, the waveform is adjusted to the dimensions and characteristics of the target of interest for the SINR maximization. Frequency, bandwidth, and pulse length as well as the polarization can be adapted to the specific situation. In addition, the optimization of energy distribution over the frequency within the pulse can improve the SINR.

The original concept of the matched filter illumination by Gjessing [27] and Bell [28] considered the optimum waveform for the detection of a target of a given range profile against noise. The target is characterized in terms of its impulse response as a function of delay time (i.e., range), which will also be a function of aspect angle (and in practice would require a library of target impulse responses versus aspect angle). The concept has been extended by Pillai et al. [29] to include detection of a target against nonhomogeneous noise, and also to the problem of discriminating different targets.

The problem is posed as follows (fig. 5) [30]. The radar transmits a signal $s(t)$ towards a target, whose impulse response is $h_{T}(t)$. The echo signal $y(t)$ is the convolution of $s(t)$ with $h_{T}(t)$. To this is added noise $n(t)$, so the received signal is

$$
r(t)=\left[s(t) \otimes h_{T}(t)\right]+n(t),
$$

where $\otimes$ denotes the convolution operator. 


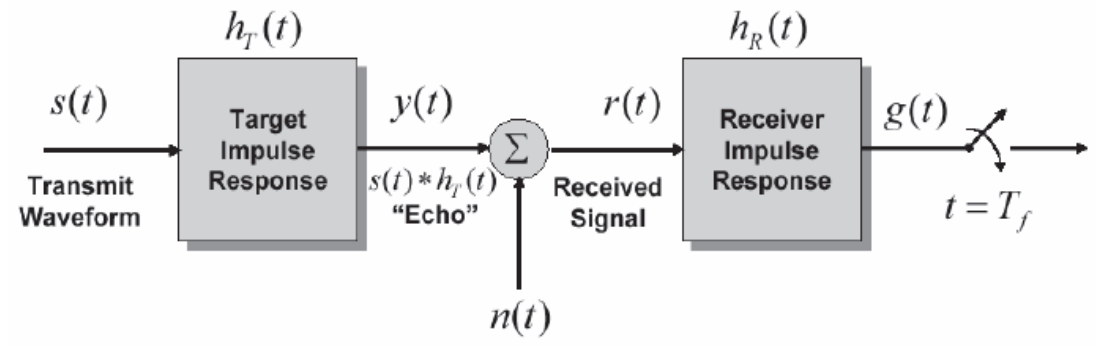

Fig. 5. The Target-Matched Illumination Problem

Source: [30, p. 7-9].

The receiver is characterized by its impulse response $h_{R}(t)$. The problem is then to choose $s(t)$ and $h_{R}(t)$ to maximise the SINR, which can be expressed in mathematical terms as follows:

$$
y_{0}=\max _{s} \max _{h} \rho\left(t_{0}\right)
$$

where $\operatorname{SINR}=\rho\left(t_{0}\right)=\frac{y_{s}^{2}\left(t_{0}\right)}{\left\langle y_{0}\left(t_{0}\right)\right\rangle^{2}}$

$y_{s}-$ is the signal component of the output;

$y_{0}-$ is the component contributed by interference and noise.

The first step is to maximize the SINR working on the receiver. Once the optimal impulse response of the receiver $h_{M F}(t)$ has been determined, it follows that:

$$
\operatorname{SINR}_{0}=\frac{1}{\sigma_{w}^{2}} \int_{T_{i}}^{T_{f}}\left|y_{w}(t)\right|^{2} d t=f(s(t)),
$$

where $T_{i}$ and $T_{f}$ - are the time boundaries of the receiver;

$$
y_{w}(t)=\left[s(t) \otimes h_{T}(t)\right]+h_{w}(t)-\text { is the signal }
$$

echo after the whitening filter with impulse response $h_{w}(t)$.

At this stage, the problem is to maximize SINR at the instant of detection $t_{0}$ over the input signal $s(t)$ of finite energy and duration. Grouping the expressions for both whitening filter and matched filter:

$$
h(t) \triangleq h_{T}(t) \otimes h_{w}(t) .
$$

Using this, the integral in (11) can be written

$$
\int_{T_{i}}^{T_{f}}\left|y_{w}(t)\right|^{2} d t=\int_{0}^{T} s\left(\tau_{1}\right) \cdot \int_{0}^{T} s^{*}\left(\tau_{2}\right) \cdot K^{*}\left(\tau_{1}, \tau_{2}\right) d \tau_{2} d \tau_{1},
$$

where

$$
K\left(\tau_{1}, \tau_{2}\right) \triangleq \int_{0}^{T} h^{*}\left(t-\tau_{1}\right) \cdot h\left(t-\tau_{2}\right) d t
$$

The solution must satisfy a homogeneous Fredholm integral of the second kind with Hermitian kernel:

$$
\lambda_{\text {max }} s_{\text {opt. }}(t)=\int_{0}^{T} s_{\text {opt. }}(\tau) \cdot K(t-\tau) d \tau
$$

This principle can be extended to different models including signal dependent noise (clutter) [29]. In this case, one must take the non-linear term into account in the SINR equation:

$$
\operatorname{SINR}_{0}=\frac{\left|\frac{1}{2 \pi} \int_{-\infty}^{\infty} H_{R}(\omega) H_{T}(\omega) S(\omega) e^{-j \omega T_{f}} d \omega\right|^{2}}{\frac{1}{2 \pi} \int_{-\infty}^{\infty}\left|H_{R}(\omega)\right|^{2}\left(G_{n}(\omega)+G_{c}(\omega)|S(\omega)|^{2}\right) d \omega},
$$

where $G_{n}(\omega)$ - is the additive noise spectrum;

$G_{c}(\omega)-$ is the clutter spectrum;

$H_{T}(\omega)$ and $H_{R}(\omega)$ - are the transmitter and receiver spectrum respectively.

From the above model, we can derive three main cases:

1) the clutter is non significant compared to the additive noise $G_{c}(\omega) \ll G_{n}(\omega)$;

$2)$ the additive noise is non significant regards to the clutter $G_{c}(\omega) \gg G_{n}(\omega)$;

3) clutter and noise are of equivalent power $G_{c}(\omega) \sim G_{n}(\omega)$.

Unlike the first two cases, which can be solved by the previous method, the third one (clutter and noise) has been studied by Pillai et al. [29] using an iterative procedure.

The practical issue with matched filter illumination is how to observe past radar returns and extract useful information in order to decide or select the radar waveform for the next transmission in some optimal fashion. For example, in strong clutter environments, there is no reason to use long pulses, as is the case for detecting weak targets. Indeed, it may be preferable to use very short pulses and higher PRFs to more rapidly obtain the space-time clutter channel estimate [31]. Moreover, there is possibility to define the optimal pulse length and PRF that maximize ratio between target and clutter echoes for defined type of target.

Knowledge-based radar signal and data processing. CFAR detection. Clutter returns and/or jamming can be much larger than receiver noise. As a consequence, the detection threshold can be exceeded, and false alarms can occur. This could overload an auto- 
matic detection and track system. Constant false alarm rate (CFAR) automatically raises the threshold level, thus avoiding overload of the automatic tracker with extraneous target reports [32]. CFAR is achieved at the expense of a lower probability of detection of desired targets. A common algorithm used in most radar systems is Cell Averaging (CA-CFAR) detector proposed in 1968 by Finn and Johnson [33]. This algorithm is optimum when the statistic of the envelope is Rayleigh distributed. It uses an adaptive threshold whose level is determined by the clutter and/or noise in the vicinity of the radar echo.

Where the distribution is not a Rayleigh and when some of the surrounding cells are of a different clutter type, there are need to use another CFAR algorithms. A set of rules were developed along with a voting scheme based on five CFAR algorithms: Cell Averaging (CA), Trimmed Mean (TM), Ordered Statistic (OS), "Greatest Of" logic (GO), "Smallest Of" logic (SO). An expert system (ES) tool was developed and simulations were performed that showed that the ES approach outperformed CA-CFAR in heterogeneous terrain [34]. The results of comparing the ES-CFAR to CA-CFAR and OS-CFAR with actual data from an E-3A radar are provided in Fig. 6 [12].

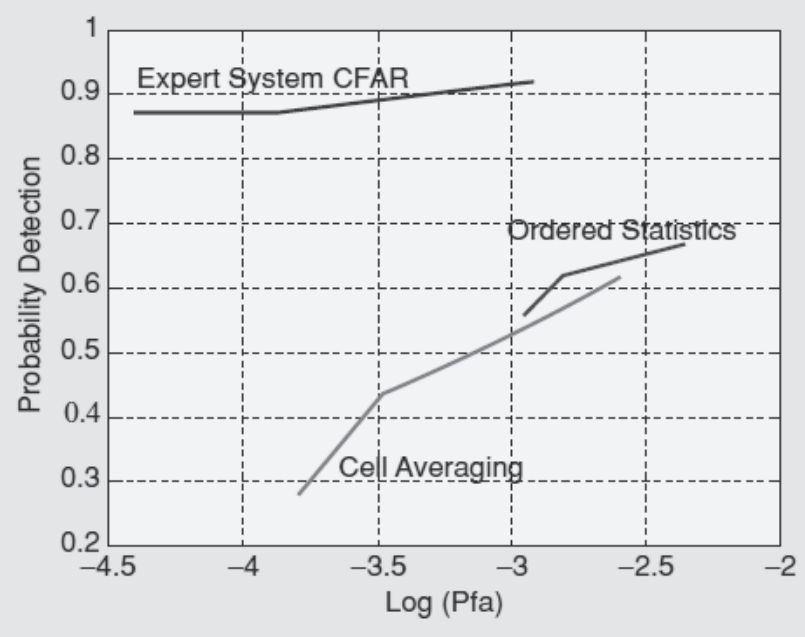

Fig. 6. ES-CFAR measured E-3A results Source: [12, p. 27].

Advisability of using Bayesian approaches for CFAR target detection was also discussed by Ya.D. Shirman and V.M. Orlenko in [21; 35]. It was demonstrated that using a priory probability densities in combination with Gaussian probability density of clutter one can obtains a versatile tool for handling a wide range of probability distributions of clutter given a moderate computational burden of signal processing algorithms. In particular, given the UWB radar signals, the authors proposed to use the so called ParetoGaussian distribution of clutter and internal noise. In this case, the Gaussian clutter and noise would feature the variance, which can't take any random value, rather the clutter variance itself must obey certain a priory distribution:

$$
p(D)=\frac{D^{\eta}}{\int_{D_{0}}^{A} D^{\eta} d D}
$$

where $D$ is the clutter variance;

$\eta-$ is the clutter distribution parameter;

$D_{0}$ - is the variance of internal noise;

$A$ - is the maximum magnitude of the mixture containing both internal noise and clutter, which is basically determined by the dynamic range of radar receiver.

Choosing parameters $\eta \leq 0, D_{0} \neq 0, A \rightarrow \infty$, one can obtain distributions, which are pretty close to the more complicated non-Gaussian distributions of clutter such as Weibull, Log-normal, K-distribution, the latter is the case given an UWB radar signal. Besides, the a priory information regarding clutter can be gathered in form of clutter map containing just few parameters like maximum power of clutter $A$ as per range resolution cell and the character of clutter peaks $\eta$.

Taking into account expression (12), the authors of [21;35] provided a transcendent expression for setting the adaptive threshold for the CFAR target detection $Z_{0}^{2}(s)$ that would depend on the magnitude of sample statistics $s$ given the preset value of false alarm per resolution cell $F$. It was also demonstrated that such Bayesian CFAR detector was indeed characterized by a stabilized false alarm rate given any magnitude of training sample statistics $s$ only if the detector was designed while accounting for parameters $\eta$ and $D_{0} \neq 0$.

Tracking. Important breakthroughs of the optimal filtering theory have been the Wiener filter for stationary processes and the Kalman-Bucy filter, which represent the optimal filter when both the dynamic state and the measurement equations are linear and the forcing and measurement noises are independent and Gaussian [32]. More over in standard problem statement forcing and measurement noises are white noise.

The problem of correlated forcing noise turns to the standard problem statement by extending of state vector. If the measurement noise is correlated process than the measurement model is complemented by additional forming equation of correlated measurement noise from white noise. These two cases are called extended Kalman-Bucy filter [36]. Its application for air defense radars are given in [37].

The nonlinear and non-Gaussian problems are solved by linearization of object movement model and replacement non-Gaussian probability density function by equivalent Gaussian density.

From the nature of movement of manned air objects it follows the object movement model where com- 
ponents of object acceleration are independent exponential correlated processes with non-Gaussian multiplepeaked probability density function [38]. This function has three peaks which corresponds uniform rectilinear motion and maneuver of maximum intensity and uniform distribution between the maximum values of acceleration. For creation of tracking system within optimal linear filtering theory the multiple-peaked probability density function is replaced by equivalent Gaussian density with acceleration variance which corresponds to the maneuver of maximum intensity. If object don't maneuver such approach provides unjustified increasing of tracking system bandwidth. To elimination of this lack multiple-alternative object movement model is proposed in [39]. In this model components of object acceleration are independent exponential correlated processes with Gaussian probability density function with known variance and unknown mathematical expectation. There are some hypotheses about mathematical expectation. The resultative estimation forms either as a result of weighted summation of partial estimations which corresponds to all hypotheses or equal one partial estimations according to maximum of a likelihood function criterion (posterior probability criterion) [40]. The similar approach based on partial movement models was developed in [41] and called Daum filtering.

Recently, the need to perform more accurate estimates in a nonlinear, non-Gaussian environment has prompted the conception of new approximations to the optimum filtering that effectively go beyond the Kalman-Bucy theory [42].

Multifunction radar resource management and cost function design. The resource management has the task to optimize the use of the available resources with respect to the current mission and situation. Knowledgebased approaches have been used in recent years to design efficient scheduling algorithms. Researchers have proposed numerous approaches [12]:

1) scheduling processes to interleave tasks using neural networks;

2) scheduling tracking and surveillance tasks based on operations research theory and on temporal logic using AI;

3) algorithms using the concept of online coupledtask scheduling where the time between the pulse transmission and reception are used for interleaving new tasks;

4) the use of fuzzy logic to introduce concepts such as dangerous and friendly in the scheduling process in order to resolve conflicts between tasks when the radar system is operating in an environment that leads to an overload situation.

The actual methods on how resource management is performed can be grouped into two major classes: Rule-based and quality-of-service (QoS) resource management [43]. With rule-based resource management, fixed rules or adaptive rules that take the estimated RCS of the target and the desired track quality into account are used. One important aspect is that the rules are applied for each task individually and the overall available resource is not taken into account. The QoS resource management methods use measures for quality to optimize the overall performance of the system regarding this measure and the available resources. This approach, therefore, requires good understanding of the utilized quality measure. The advantage of the QoS approach is that, even in the dense scenarios, the available resource is distributed among the tasks to still maximize the performance of the system and no predefined priority that may or may not be applicable in the current situation has to be used to solve the conflicts. Some strategies for developing cost functions for executive processor optimization by combining performance and measurement metrics provided in [44].

QoS methods circumvent the problem of combining task performance measures by combining and optimizing utilities, which represent the mission-relevant satisfaction that is associated with a task performance level, leading to mission relevant resource allocation. This issue of cost and reward function design remains more of an art than a science, and will continue to be a major research challenge [17].

\section{Conclusions}

In order to manage today's and upcoming challenges, such as low flying small and slow drone swarms [45] up to hypersonic maneuvering missiles, cognitive radars are a prerequisite. At current moment there are several experimental cognitive radars testbeds: the KASSPER HPEC system (MIT Lincoln Laboratory in conjunction with DARPA) [20], the CREW system (Cognitive Sensing Laboratory at the Ohio State University in conjunction with Air Force Research Laboratory) [46] and the CODIR system (Buro fur Sensorik und Signalverarbeitung in conjunction with Armasuisse Science and Technology) [47]. All these testbeds, through adaptation of pulse bandwidth, PRF, coherent processing interval, etc., demonstrate how the cognitive approach can yield superior performance and what might be possible using it to radar system design.

The remaining question is more one of developing the theory and application of adaptive transmit functionality. Another important area for future research is improved techniques for blending the various channel estimates. i.e., $\widehat{\mathbf{R}}_{S}, \widehat{\mathbf{R}}_{M}$ and $\widehat{\mathbf{R}}_{K A}$. Extension of the technique to incorporate rank and structure constraints on the clutter covariance matrix would be an important future direction. 


\section{References}

1. NATO Science \& Technology Organization (2020), Science \& Technology Trends 2020-2040. Exploring the S\&T Edge: Report. Available at: https://www.nato.int/nato_static_fl2014/assets/pdf/2020/4/pdf/190422-ST_Tech_Trends_Report_20202040.pdf (accessed 20.03.2021).

2. Franklin, J., Carmody, C., Kelle,r K., Levitt, T. and Buteau, B. (1988), Expert system technology for the military: selected samples, Proceedings of the IEEE, Vol. 76, No. 10, pp. 1327-1366. https://doi.org/10.1109/5.16329.

3. The official site Intel, Neuromorphic Computing, Available at: https://www.intel.co.uk/content/www/uk/ en/research/neuromorphic-computing.html (accessed 27.03.2021).

4. IEEE-SA Standards Board (2017), IEEE Std 686-2017. IEEE Standard for Radar Definitions [approved 2017-03-23], New York, $52 \mathrm{p}$.

5. Horne, C., Ritchie, M. and Griffiths, H. (2018), Proposed ontology for cognitive radar systems, IET Radar, Sonar \& Navigation, Vol. 12, No. 12, pp. 1363-1370. https://doi.org/10.1049/iet-rsn.2018.5280.

6. Haykin, S. (2006), Cognitive radar: a way of the future, IEEE Signal Processing Magazine, Vol. 23, No. 1, pp. 30-40. https://doi.org/10.1109/MSP.2006.1593335.

7. Haykin, S. (2012), Cognitive dynamic systems: perception-action cycle, radar, and radio, Cambridge University Press, Cambridge, $309 \mathrm{p}$.

8. Guerci, J. (2011), Cognitive Radar: the next Radar Wave? Microwave Journal, No. 1. pp. 22-36.

9. Guerci, J. (2010), Cognitive Radar: The Knowladge-Aided Fully Adaptive Approach, Artech House, Norwood, 175 p.

10. Van Trees, H.L. (2001), Detection, Estimation and Modulation Theory, Part I, Wiley, New York, 692 p.

11. Guerci, J., Guerci, R., Ranagaswamy, M., Bergin, J. and Wicks, M. (2014), CoFAR: Cognitive fully adaptive radar. 2014 IEEE Radar Conference: conference paper, Cincinnati, pp. 984-989. https://doi.org/10.1109/RADAR.2014.6875736.

12. Capraro, G., Farina, A., Griffiths, H. and Wicks, M. (2006), Knowledge-based radar signal and data processing: a tutorial review. IEEE Signal Processing Magazine, Vol. 23, No. 1, pp. 18-29. https://doi.org/10.1109/MSP.2006.1593334.

13. Gini, F. and Rangaswamy, M. (2008), Knowledge based radar detection, tracking, and classification, John Wiley \& Sons, $268 \mathrm{p}$.

14. Farina, A., Maio, A. and Haykin, S. (2017), The Impact of Cognition on Radar Technology, The Institution of Engineering and Technology, London, $278 \mathrm{p}$.

15. Cui, G., Maio, A. and Farina, A. (2020), Radar Waveform Design Based on Optimization Theory, The Institution of Engineering and Technology, London, $324 \mathrm{p}$.

16. Greco, M., Gini, F., Stinco, P. and Bell, K. (2018), Cognitive Radars: On the Road to Reality, IEEE Signal Processing Magazine, Vol. 35, No. 4, pp. 112-125. https://doi.org/10.1109/MSP.2018.2822847.

17. Gurbuz, S., Griffiths, H. and Charlish, A. (2019), An Overview of Cognitive Radar: Past, Present, and Future, IEEE Aerospace and Electronic Systems Magazine, Vol. 34, No. 12, pp. 6-18. https://doi.org/10.1109/MAES.2019.2953762.

18. Reed, I., Mallett, J. and Brennan, L. (1974), Rapid Convergence Rate in Adaptive Arrays, IEEE Transactions on Aerospace and Electronic Systems, Vol. 10, No. 6, pp. 853-863. https://doi.org/10.1109/TAES.1974.307893.

19. Bayes, T. (1763), An Essay Towards Solving a Problem in the Doctrine of Chances, Philosophical Transactions of the Royal Society of London, Vol. 53, pp. 370-418. https://doi.org/10.1098/rstl.1763.0053.

20. Guerci, J. and Baranoski, E. (2006), Knowledge-aided adaptive radar at DARPA: an overview, IEEE Signal Processing Magazine, Vol. 23, No. 1, pp. 41-50. https://doi.org/10.1109/MSP.2006.1593336.

21. Shirman, Y. and Orlenko, V. (2009), "K peresmotru posledstvyj fysherovskoj matematycheskoj statystyky prymenyteljno k razlychnym oblastjam nauky" [Reconsidering the implications of Fischer's mathematical statistics as applied to various fields of science]. Applied Radio Electronics, Vol. 8, No. 4, pp. 426-442.

22. Shirman, Y. and Orlenko, V. (2006), Bayesian Theory of the "Pareto-optimal" STAP Devices. 2006 International Radar Symposium : conference paper. Krakow, 24-26 May 2006. https://doi.org/10.1109/IRS.2006.4338011.

23. Abramovich, Yu. (1981), "Reghuljaryzovannyj metod adaptyvnoj optymyzacyy fyljtrov po kryteryju maksymuma otnoshenyja syghnal/pomekha" [Regularized method for adaptive filter optimization based on the criterion of maximum signalto-interference ratio], Radio engineering and electronics, No. 3, pp. 543-551.

24. Steiner, M. and Gerlach, K. (1998), Fast-converging maximum-likelihood interference cancellation, Proceedings of the 1998 IEEE Radar Conference, RADARCON'98. Challenges in Radar Systems and Solutions: conference paper, Dallas. https://doi.org/10.1109/NRC.1998.677987.

25. Stinco, P., Greco, M., Gini, F. and Himed, B. (2016), Cognitive radars in spectrally dense environments, IEEE Aerospace and Electronic Systems Magazine, Vol. 31, No. 10, pp. 20-27. https://doi.org/10.1109/MAES.2016.150193.

26. Zhao, Y., Morales, L., Gaeddert, J., Bae, K., Um, J.-S. and Reed, J. (2007), Applying radio environment maps to cognitive wireless regional area networks, Proc. 2007 2nd IEEE Int. Symp. New Frontiers Dynamic Spectrum Access: conference paper, Dublin, pp. 115-118. https://doi.org/10.1109/DYSPAN.2007.22.

27. Gjessing, D. (1986), Target Adaptive Matched Illumination Radar: Principles and Applications, Peter Peregrinus Ltd, London, $172 \mathrm{p}$.

28. Bell M. (1993), Information theory and radar waveform design, IEEE Transactions on Information Theory, Vol. 39, No. 5, pp. 1578-1597. https://doi.org/10.1109/18.259642.

29. Pillai, S., Youla, D., Oh, H. and Guerci, J. (1999), Optimum transmit-receiver design in the presence of signaldependent interference and channel noise, Conference Record of the Thirty-Third Asilomar Conference on Signals, Systems, and Computers: conference paper, Pacific Grove. https://doi.org/10.1109/ACSSC.1999.831834. 
30. Griffiths, H. (2006), Impact of Knowledge-Based Techniques on Emerging Technologies, STO Educational Notes: RTO-EN-SET-063bis. Paper 7. Available at: https://www.sto.nato.int/publications/STO\%20Educational\%20Notes/RTO-ENSET-063bis/EN-SET-063bis-07.pdf (accessed 20.03.2021).

31. Zaycev, G. (2015), "Cyfrovaja obrabotka syghnalov v mnoghofunkcyonaljnykh radyolokatorakh. Metody. Alghorytmy. Apparatura" [Digital signal processing in multifunction radars. Methods. Algorithms. Equipment], Radiotechnika, Moscow, $376 \mathrm{p}$.

32. Shirman, J. (2007), "Radyoelektronnye systemy: osnovy postroenyja y teoryja. Spravochnyk. Yzd. 2-e" [Radioelectronic systems: the basics of construction and theory. Reference book. 2nd ed], Radiotechnika, Moscow, $512 \mathrm{p}$.

33. Finn, H. and Johnson, R. (1968), Adaptive Detection Mode with Threshold Control as a Function of Specially Sampled Clutter Estimates, RCA Review, Vol. 29, No. 3, pp. 414-464. Available at: https://worldradiohistory.com/ARCHIVE-RCA/RCAReview/RCA-Review-1968-09.pdf (accessed 20.03.2021).

34. Patent USA № US5499030A (1996), Expert system constant false alarm rate (CFAR) processor, pending 18.03.1994; publ. 12.03.1996.

35. Shirman, Y. and Orlenko, V. (2006), Bayesian Theory of the "Pareto-optimal" CFAR Detectors, 2006 International Radar Symposium: conference paper, Krakow. https://doi.org/10.1109/IRS.2006.4338006.

36. Sage, Andrew P. and Melsa, James L. (1976), "Teoryja ocenyvanyja y ee prymenenye v svjazy y upravlenyy" [Estimation Theory with Applications to Communications and Control], Communication, Moscow, $496 \mathrm{p}$.

37. Sachuk, I., Kushch, P., Kalyta, A., Open'ko, P., Orlenko, V. and Bondarenko, S. (2020), The results of system analysis of functional diagrams and operation algorithms of tracking systems of tracking radar of antiaircraft missile armament with digital processing of error signal, 2020 IEEE International Conference on Advanced Trends in Information Theory, pp. 181-185.

38. Singer, Robert A. (1970), Estimating Optimal Tracking Filter Performance for Manned Maneuvering Objects, IEEE Transactions on Aerospace and Electronic Systems, Vol. 6, Issue 4, pp. 473-483.

39. Hismatulin, V. and Sachuk, I. (1998), "Mnoghoaljternatyvnaja modelj dvyzhenyja manevryrujushhej cely" [Multiplealternative movement model of maneuvering target], Collection of Scientific Papers of Kharkiv military university, Vol. 21, pp. 71-75.

40. Sachuk, I. (2015), "Realizacija paraleljnoji filjtraciji rezuljtativ vymirjuvanj u systemakh suprovodzhennja zenitnykh raketnykh kompleksiv" [The practical usage of parallel filtration of measuring results in tracking systems of surface to air complexes], Science and Technology of the Air Force of Ukraine, No. 4(21), pp. 55-57.

41. Daum, F. (2005), Nonlinear Filters: Beyond the Kalman Filter, IEEE A\&S System Magazine, Vol. 20, No. 8, Part 2, pp. 57-68.

42. Ristic, B., Arulampalam, S. and Gordon, N. (2004), Beyond the Kalman Filter: Tracking Applications of Particle Filters, Artech House, Norwood. $176 \mathrm{p}$.

43. Bockmair, M., Fischer, Ch., Letsche-Nuesseler, M., Neumann, Ch., Schikorr, M. and Steck, M. (2019), Cognitive Radar Principles for Defence and Security Applications, IEEE Aerospace and Electronic Systems Magazine, Vol. 34, No. 12, pp. 20-29. https://doi.org/10.1109/MAES.2019.2953802.

44. Mitchell, A., Smith, G. and Bell, K. (2018), Cost function design for the fully adaptive radar framework, IET Radar, Sonar \& Navigation, Vol. 12, No. 12, pp. 1380-1389. https://doi.org/10.1049/iet-rsn.2018.5327.

45. Dudush, A., Tyutyunnik, V., Trofimov, I., Bortnovs'kiy, S. and Bondarenko, S. (2018), State of the Art and Problems of Defeat of Low, Slow and Small Unmanned Aerial Vehicles, Advances in Military Technology, Vol. 13, No. 2, pp. 157-171. https://doi.org/10.3849/aimt.01233.

46. Smith, G., Cammenga, Z., Mitchell, A., Bell, K., Johnson, J. and Rangaswamy, M. (2016), Experiments with cognitive radar. IEEE Aerospace and Electronic Systems Magazine, Vol.31, No. 12, pp. 34-46. https://doi.org/10.1109/MAES.2016.150215.

47. Oechslin, R., Wieland, S., Hinrichsen, S., Aulenbacher, U. and Wellig, P. (2019), A Cognitive Radar Testbed for Outdoor Experiments, IEEE Aerospace and Electronic Systems Magazine, Vol. 34, No. 12, pp. 40-48. https://doi.org/10.1109/MAES.2019.2956802.

\section{Список літератури}

1. NATO Science \& Technology Organization. Science \& Technology Trends 2020-2040. Exploring the S\&T Edge : Report. URL: https://www.nato.int/nato_static_fl2014/assets/pdf/2020/4/pdf/190422-ST_Tech_Trends_Report_2020-2040.pdf (accessed 20.03.2021).

2. Franklin J., Carmody C., Keller K., Levitt T., Buteau B. Expert system technology for the military : selected samples, Proceedings of the IEEE. 1988. Vol. 76. No. 10. P. 1327-1366. https://doi.org/10.1109/5.16329.

3. Neuromorphic Computing. Intel : web site. URL: https://www.intel.co.uk/content/www/uk/en/research/neuromorphiccomputing.html (accessed 27.03.2021).

4. IEEE Std 686-2017. IEEE Standard for Radar Definitions. [чинний від 2017-03-23]. Вид. офіц. New York : IEEE-SA Standards Board, 2017. $52 \mathrm{c}$.

5. Horne C., Ritchie M., Griffiths H. Proposed ontology for cognitive radar systems. IET Radar, Sonar \& Navigation. 2018. Vol. 12. No. 12. P. 1363-1370. https://doi.org/10.1049/iet-rsn.2018.5280.

6. Haykin S. Cognitive radar : a way of the future. IEEE Signal Processing Magazine. 2006. Vol. 23. No. 1. P. 30-40. https://doi.org/10.1109/MSP.2006.1593335. 
7. Haykin S. Cognitive dynamic systems : perception-action cycle, radar, and radio. Cambridge : Cambridge University Press, 2012. 309 p.

8. Guerci J. Cognitive Radar : the next Radar Wave? Microwave Journal. 2011. No. 1. P. 22-36.

9. Guerci J. Cognitive Radar: The Knowladge-Aided Fully Adaptive Approach. Norwood : Artech House, 2010. 175 p.

10. Van Trees H.L. Detection, Estimation and Modulation Theory, Part I. New York : Wiley, 2001. 692 p.

11. Guerci J., Guerci R., Ranagaswamy M., Bergin J., Wicks M. CoFAR : Cognitive fully adaptive radar. 2014 IEEE Radar Conference : conference paper. Cincinnati. 19-23 May 2014. P. 984-989. https://doi.org/10.1109/RADAR.2014.6875736.

12. Capraro G., Farina A., Griffiths H., Wicks M. Knowledge-based radar signal and data processing : a tutorial review. IEEE Signal Processing Magazine. 2006. Vol. 23. No. 1. P. 18-29. https://doi.org/10.1109/MSP.2006.1593334.

13. Gini F., Rangaswamy M. Knowledge based radar detection, tracking, and classification. John Wiley \& Sons, 2008. $268 \mathrm{p}$.

14. Farina A., Maio A., Haykin S. The Impact of Cognition on Radar Technology. London : The Institution of Engineering and Technology, 2017. $278 \mathrm{p}$.

15. Cui G., Maio A., Farina A. Radar Waveform Design Based on Optimization Theory. London : The Institution of Engineering and Technology, 2020. 324 p.

16. Greco M., Gini F., Stinco P., Bell K. Cognitive Radars : On the Road to Reality. IEEE Signal Processing Magazine. 2018. Vol. 35. No. 4. P. 112-125. https://doi.org/10.1109/MSP.2018.2822847.

17. Gurbuz S., Griffiths H., Charlish A. An Overview of Cognitive Radar : Past, Present, and Future. IEEE Aerospace and Electronic Systems Magazine. 2019. Vol. 34. No. 12. P. 6-18. https://doi.org/10.1109/MAES.2019.2953762.

18. Reed I., Mallett J., Brennan L. Rapid Convergence Rate in Adaptive Arrays. IEEE Transactions on Aerospace and Electronic Systems. 1974. Vol. 10. No. 6. P. 853-863. https://doi.org/10.1109/TAES.1974.307893.

19. Bayes T. An Essay Towards Solving a Problem in the Doctrine of Chances. Philosophical Transactions of the Royal Society of London. 1763. Vol. 53. P. 370-418. https://doi.org/10.1098/rstl.1763.0053.

20. Guerci J., Baranoski E. Knowledge-aided adaptive radar at DARPA : an overview. IEEE Signal Processing Magazine. 2006. Vol. 23. No. 1. P. 41-50. https://doi.org/10.1109/MSP.2006.1593336.

21. Ширман Я. Д., Орленко В. М. К пересмотру последствий фишеровской математической статистики применительно к различным областям науки. Прикладная радиоэлектроника. 2009. Т. 8. № 4. С. 426-442.

22. Shirman Y., Orlenko V. Bayesian Theory of the "Pareto-optimal" STAP Devices. 2006 International Radar Symposium : conference paper. Krakow, 24-26 May 2006. https://doi.org/10.1109/IRS.2006.4338011.

23. Абрамович Ю.И. Регуляризованный метод адаптивной оптимизации фильтров по критерию максимума отношения сигнал/помеха. Радиотехника и электроника. 1981. № 3. С. 543-551.

24. Steiner M., Gerlach K. Fast-converging maximum-likelihood interference cancellation. Proceedings of the 1998 IEEE Radar Conference, RADARCON'98. Challenges in Radar Systems and Solutions : conference paper. Dallas, 14 May 1998. https://doi.org/10.1109/NRC.1998.677987.

25. Stinco P., Greco M., Gini F., Himed B. Cognitive radars in spectrally dense environments. IEEE Aerospace and Electronic Systems Magazine. 2016. Vol. 31. No. 10. P. 20-27. https://doi.org/10.1109/MAES.2016.150193.

26. Zhao Y., Morales L., Gaeddert J., Bae K., Um J.-S., Reed J. Applying radio environment maps to cognitive wireless regional area networks. Proc. 2007 2nd IEEE Int. Symp. New Frontiers Dynamic Spectrum Access : conference paper. Dublin, 17-20 April 2007. P. 115-118. https://doi.org/10.1109/DYSPAN.2007.22.

27. Gjessing D. Target Adaptive Matched Illumination Radar : Principles and Applications. London : Peter Peregrinus Ltd, 1986. $172 \mathrm{p}$.

28. Bell M. Information theory and radar waveform design. IEEE Transactions on Information Theory. 1993. Vol. 39. No. 5. P. 1578-1597. https://doi.org/10.1109/18.259642.

29. Pillai S., Youla D., Oh H., Guerci J. Optimum transmit-receiver design in the presence of signal-dependent interference and channel noise. Conference Record of the Thirty-Third Asilomar Conference on Signals, Systems, and Computers : conference paper. Pacific Grove, 24-27 Oct. 1999. https://doi.org/10.1109/ACSSC.1999.831834.

30. Griffiths H. Impact of Knowledge-Based Techniques on Emerging Technologies. STO Educational Notes : RTO-ENSET-063bis. 2006. Paper 7. URL: https://www.sto.nato.int/publications/STO\%20Educational\%20Notes/RTO-EN-SET063bis/EN-SET-063bis-07.pdf (accessed 20.03.2021).

31. Цифровая обработка сигналов в многофункциональных радиолокаторах. Методы. Алгоритмы. Аппаратура / под. ред. Г. В. Зайцева. Москва : Радиотехника, 2015. 376 с.

32. Радиоэлектронные системы: основы построения и теория. Справочник. Изд. 2-е, перераб. и доп. / под ред. Я.Д. Ширмана. Москва : Радиотехника, 2007. 512 с.

33. Finn H., Johnson R. Adaptive Detection Mode with Threshold Control as a Function of Specially Sampled Clutter Estimates. RCA Review. 1968. Vol. 29. No. 3. P. 414-464. URL: https://worldradiohistory.com/ARCHIVE-RCA/RCAReview/RCA-Review-1968-09.pdf (accessed 20.03.2021).

34. Expert system constant false alarm rate (CFAR) processor : пат. США : № US5499030А; заявл. 18.03.1994; опубл. 12.03.1996.

35. Shirman Y., Orlenko V. Bayesian Theory of the "Pareto-optimal" CFAR Detectors. 2006 International Radar Symposium : conference paper. Krakow, 24-26 May 2006. https://doi.org/10.1109/IRS.2006.4338006.

36. Сейдж А, Мелса Дж. Теория оценивания и ее применение в связи и управлении. Москва : Связь, 1976. 496 с. 
37. Sachuk I., Kushch P., Kalyta A., Open'ko P., Orlenko V., Bondarenko S. The results of system analysis of functional diagrams and operation algorithms of tracking systems of tracking radar of antiaircraft missile armament with digital processing of error signal. 2020 IEEE International Conference on Advanced Trends in Information Theory. 2020. P. 181-185.

38. Singer Robert A. Estimating Optimal Tracking Filter Performance for Manned Maneuvering Objects. IEEE Transactions on Aerospace and Electronic Systems. 1970. Vol. 6. Issue 4. P. 473-483.

39. Хисматулин В. Ш., Сачук И. И. Многоальтернативная модель движения маневрирующей цели. Збірник наукових праць ХВУ. 1998. Вип. 21. С. 71-75.

40. Сачук I.I. Реалізація паралельної фільтрації результатів вимірювань у системах супроводження зенітних ракетних комплексів. Наука і техніка Повітряних Сил Збройних Сил Украйни. 2015. № 4(21). С. 55-57.

41. Daum F. Nonlinear Filters : Beyond the Kalman Filter. IEEE A\&S System Magazine. 2005. Vol. 20. No. 8. Part 2. P. 57-68.

42. Ristic B., Arulampalam S., Gordon N. Beyond the Kalman Filter : Tracking Applications of Particle Filters. Norwood : Artech House, 2004. 176 p.

43. Bockmair M., Fischer Ch., Letsche-Nuesseler M., Neumann Ch., Schikorr M., Steck M. Cognitive Radar Principles for Defence and Security Applications. IEEE Aerospace and Electronic Systems Magazine. 2019. Vol. 34. No. 12. P. $20-29$. https://doi.org/10.1109/MAES.2019.2953802.

44. Mitchell A., Smith G., Bell K. Cost function design for the fully adaptive radar framework. IET Radar, Sonar \& Navigation. 2018. Vol. 12. No. 12. P. 1380-1389. https://doi.org/10.1049/iet-rsn.2018.5327.

45. Dudush A., Tyutyunnik V., Trofimov I., Bortnovs'kiy S., Bondarenko S. State of the Art and Problems of Defeat of Low, Slow and Small Unmanned Aerial Vehicles. Advances in Military Technology. 2018. Vol. 13. No. 2. P. 157-171. https://doi.org/10.3849/aimt.01233.

46. Smith G., Cammenga Z., Mitchell A., Bell K., Johnson J., Rangaswamy M. Experiments with cognitive radar. IEEE Aerospace and Electronic Systems Magazine. 2016. Vol. 31. No. 12. P. 34-46. https://doi.org/10.1109/MAES.2016.150215.

47. Oechslin R., Wieland S., Hinrichsen S., Aulenbacher U., Wellig P. A Cognitive Radar Testbed for Outdoor Experiments. IEEE Aerospace and Electronic Systems Magazine. 2019. Vol. 34. No. 12. P. $40-48$. https://doi.org/10.1109/MAES.2019.2956802.

Received by Editorial Board 10.08.2021

Signed for Printing 14.09.2021

\section{Відомості про авторів:}

\section{Дудуш Анатолій Сергійович}

кандидат технічних наук доцент

доцент кафедри Харківського національного

університету Повітряних Сил ім. І. Кожедуба, Харків, Україна

https://orcid.org/0000-0002-8454-2127

\section{Сачук Ігор Іванович}

кандидат технічних наук доцент

начальник кафедри Харківського національного університету Повітряних Сил ім. І. Кожедуба, Харків, Україна

https://orcid.org/0000-0002-0110-8297

\section{Оваід Сальман Рашид}

кандидат технічних наук

викладач коледжу університету Аль Мареф

Анбар, Ірак

https://orcid.org/0000-0002-1189-9707

\section{Бідун Андрій Костянтинович}

викладач Харківського національного

університету Повітряних Сил ім. І. Кожедуба,

Харків, Україна

https://orcid.org/0000-0002-4789-9397

\section{Information about the authors:}

\section{Anatolii Dudush}

Candidate of Technical Sciences Assistant Professor

Senior Lecturer of Ivan Kozhedub

Kharkiv National Air Force University,

Kharkiv, Ukraine

https://orcid.org/0000-0002-8454-2127

\section{Ihor Sachuk}

Candidate of Technical Sciences Assistant Professor

Head of Department of Ivan Kozhedub

Kharkiv National Air Force University,

Kharkiv, Ukraine

https://orcid.org/0000-0002-0110-8297

\author{
Salman Owaid \\ Candidate of Technical Sciences \\ Instructor of Al Maaref University Collage, \\ Anbar, Iraq \\ https://orcid.org/0000-0002-1189-9707
}

\author{
Andrii Bidun \\ Instructor of Ivan Kozhedub \\ Kharkiv National Air Force University, \\ Kharkiv, Ukraine \\ https://orcid.org/0000-0002-4789-9397
}




\section{НАУКОВІ ТА ТЕХНОЛОГІЧНІ ТЕНДЕНЦІЇ У КОНЦЕПЦІЇ КОГНІТИВНИХ РЛС}

\section{А.С. Дудуш, І.І. Сачук, Оваід Сальман, А.К. Бідун}

В даний час когнітивний процес в РЛС забезпечується людьми-операторами. Однак досягнення в "иифровізачії" пристроїв РЛС, включаючи циифрові генератори сигналів довільної форми і високопродуктивні вбудовані системи обчислень, дозволяють змінювати всі ключові параметри РЛС (потужність, тривалість імпульсу, кількість імпульсів, частоту повторення імпульсів, модуляцію, частоту, поляризацію) для кожного імпульсу в межах нс або мкс в широкому робочому діапазоні. Ця часова шкала набагато швидше, ніж здатність людини-оператора приймати рішення. Когнітивні методи в РЛС, які інтенсивно розвиваються в останні роки, імітують елементи людського пізнання і використовують зовнішню інформацію з метою оптимального застосування доступних системних ресурсів для досягнення поточної мети в заданих умовах функціонування. РЛС, функціонування яких засноване на циклі сприйняття-дії когнітивного прочесу, який полягає у взаємодї з навколишнім середовищем, отриманні відповідної інформації про цілі та навколишнє середовище, а потім адаптаџії параметрів РЛС для оптимального задоволення потреб місії відповідно до необхідної мети, називаються когнітивними РЛС. У статті проведено аналіз нових ідей і областей застосування когнітивних РЛС.

Ключові слова: когнітивна РЛС, просторово-часова адаптивна обробка (ПЧАО), байєсівська фільтрачія, інтелектуальна обробка радіолокаџійних сигналів і радіолокаџійної інформації.

\section{НАУЧНЫЕ И ТЕХНОЛОГИЧЕСКИЕ ТЕНДЕНЦИИ В КОНЦЕПЦИИ КОГНИТИВНЫХ РЛС}

\section{А.С. Дудуш, И.И. Сачук, Оваид Сальман, А.К. Бидун}

В настоящее время когнитивный процесс в РЛС обеспечивается людьми-операторами. Однако достижения в “иифровизации” устройств РЛС, включая иифровые генераторы сигналов произвольной формы и высокопроизводительные встраиваемые системы вычислений, позволяют изменять все ключевые параметры РЛС (мощность, длительность импульса, количество импульсов, частоту повторения импульсов, модуляиию, частоту, поляризаиию) для каждого импульса в пределах нс или мкс в широком рабочем диапазоне. Эта временная шкала намного быстрее, чем способность человека-оператора принимать решения. Когнитивные методы в РЛС, которые интенсивно развиваются 8 последние годы, имитируют элементы человеческого познания и используют внешнюю информацию с иелью оптимального применения доступных системных ресурсов для достижения текущей иеели в заданных условиях функционирования. РЛС, функционирование которых основано на иикле восприятия-действия когнитивного процесса, который заключается во взаимодействии с окружающей средой, получении соответствующей информации о иели и окружающей среде, а затем адаптации параметров РЛС для оптимального удовлетворения потребностей миссии в соответствии с требуемой целью, называются когнитивными РЛС. В статье проведен анализ новейших идей и областей применения когнитивных РЛС.

Ключевые слова: когнитивная РЛС, пространственно-временная адаптивная обработка (ПВАО), байесовская фильтрачия, интеллектуальная обработка радиолокачионных сигналов и радиолокационной информации. 